\title{
Incidence of Micronuclei and Abnormalities in the Head of Spermatozoa Caused by the Salts of a Heavy Metal, Nickel
}

\author{
R. C. Sobti and R. K. Gill \\ Department of Zoology, Panjab University, Chandigarh 160014, India
}

Accepted April 11, 1988

Micronuclei, the cytoplasmic chromatin masses that look like very small nuclei, arise from chromosomes lagging at anaphase or from acentric chromosomal fragments resulting from mitotic/meiotic disturbances. Although they were known for many years (Brenneke 1937, Mather 1937, Thoday 1951, Russel and Russel 1954, Evans et al. 1959), their real importance was recognized in the late 1960 s and early 1970s when Heddle (1973) developed the bonemarrow micronucleus test. Today this is widely used as a screening system for the detection of compounds that cause chromosome mutations. Wyrobek and Bruce (1975) also indicated that the effect of environmental mutagens can also be assessed by determining the frequency of abnormalities in the head of spermatozoa. Although the exact genetic significance of this test is not known, it is being frequently used in the various screening programmes. During the present work we have used both of these parameters to determine the effect of the various salts of nickel on mice, because it is a suspect carcinogen (Doll et al. 1970, Sunderman 1978, 1984, Chovil et al. 1981) and the available data on its mutagenic potential are quite contradictory.

\section{Material and methods}

Mice of the lacca strain were purchased from the Central Research Institute, Kasauli (India) and were bred at $25 \pm 2^{\circ} \mathrm{C}$ in a specially equipped room. The stock solutions of the nickel compounds viz., $\mathrm{NiCl}_{2}$ (CAS No. 7718-54-9), $\mathrm{NiSO}_{4}\left(\mathrm{CAS} \mathrm{No}\right.$.7786-81-4) and $\mathrm{NiNO}_{3}$ (CAS No. 131-38-49) were made in distilled water and administered orally. A parallel concontrol was kept in each case. For the detection of micronuclei, the animals were treated for 6 and 30 hours with the chemicals and smears of the bone-marrow were made in 1: 1 phosphate buffer and fetal calf serum (Robert and Bernard 1982). The air dried slides were stained in May-Grunwald's Giemsa stain (Schmid 1973, 1975). The micronuclei were studied in young polychromatic erythrocytes (PCEs).

The smears of spermatozoa from the epididymis were made after five weeks of the last exposure (Wyrobek and Bruce 1975). These were stained in Giemsa. The abnormalities in the heads of spermatozoa were detected under the oil immersion lens of a Carl Zeiss photomicroscope.

\section{Results}

The data on the frequency of micronuclei and sperm head abnormalities are presented in Table 1. It is evident from this that all the three compounds induced a statistically significant number of micronuclei. In a few PCEs, two micronuclei were also seen (Figs. 1A-I). The effect in all the cases was dose related. Similarly the frequency of abnormalities induced in the head of the spermatozoa by these chemicals was also significant being $22.66 \pm 2.179,25.66 \pm$ 0.982 and $32.33 \pm 1.870$ with $\mathrm{NiCl}_{2} \mathrm{NiSO}_{4}$ and $\mathrm{NiNO}_{3}$ respectively as against $8.66 \pm 0.541$ 
Table 1. Frequency of the micronuclei and abnormalities in the head of the spermatozoa induced by the various compounds of nickel

\begin{tabular}{|c|c|c|c|c|c|}
\hline Assay & Chemical & Dose & Route & $\begin{array}{l}\text { Time of } \\
\text { sampling }\end{array}$ & Mean \pm S.E. \\
\hline Micronuclei & $\begin{array}{l}\text { Control } \\
\mathrm{NiNO}_{3} \\
\mathrm{NiCl}_{2} \\
\mathrm{NiSO}_{4} \\
\text { Control } \\
\mathrm{NiNO}_{3} \\
\mathrm{NiCl}_{2} \\
\mathrm{NiSO}_{4}\end{array}$ & $\begin{array}{l}\mathrm{H}_{2} \mathrm{O} \\
72.2 \mathrm{mg} / \mathrm{kg} \\
95 \mathrm{mg} / \mathrm{kg} \\
73 \mathrm{mg} / \mathrm{kg} \\
\mathrm{H}_{2} \mathrm{O} \\
72.2 \mathrm{mg} / \mathrm{kg} \\
95 \mathrm{mg} / \mathrm{kg} \\
73 \mathrm{mg} / \mathrm{kg}\end{array}$ & $\begin{array}{l}\text { Oral } \\
\text { " } \\
\text { " } \\
\text { " } \\
\text { " } \\
\text { " }\end{array}$ & $\begin{array}{c}6 \text { hours } \\
\text { " } \\
\text { " } \\
\text { " } \\
30 \text { hours } \\
" \\
" \\
"\end{array}$ & $\begin{array}{l}1.33 \pm 0.272 \\
2.66 \pm 0.720^{*} \\
3.80 \pm 0.815^{*} \\
2.33 \pm 0.272^{*} \\
1.66 \pm 0.272 \\
4.66 \pm 0.720^{*} \\
5.00 \pm 0.948^{*} \\
4.33 \pm 0.272^{*}\end{array}$ \\
\hline $\begin{array}{l}\text { Sperm head } \\
\text { abnormalities }\end{array}$ & $\begin{array}{l}\text { Control } \\
\mathrm{NiNO}_{3} \\
\mathrm{NiCl}_{2} \\
\mathrm{NiSO}_{4}\end{array}$ & $\begin{array}{l}\mathrm{H}_{2} \mathrm{O} \\
72.2 \mathrm{mg} / \mathrm{kg} \\
95 \mathrm{mg} / \mathrm{kg} \\
73 \mathrm{mg} / \mathrm{kg}\end{array}$ & $\begin{array}{l}\text { " } \\
" 1 \\
\text { " }\end{array}$ & $\begin{array}{c}5 \text { weeks } \\
" 1 \\
" \\
" 1\end{array}$ & $\begin{array}{c}8.66 \pm 0.547 \\
32.33 \pm 1.870^{* *} \\
22.66 \pm 2.179^{* *} \\
25.66 \pm 0.982^{* *}\end{array}$ \\
\hline
\end{tabular}

${ }^{*} \mathrm{p}<0.05$

$* * \mathrm{p}<0.01$

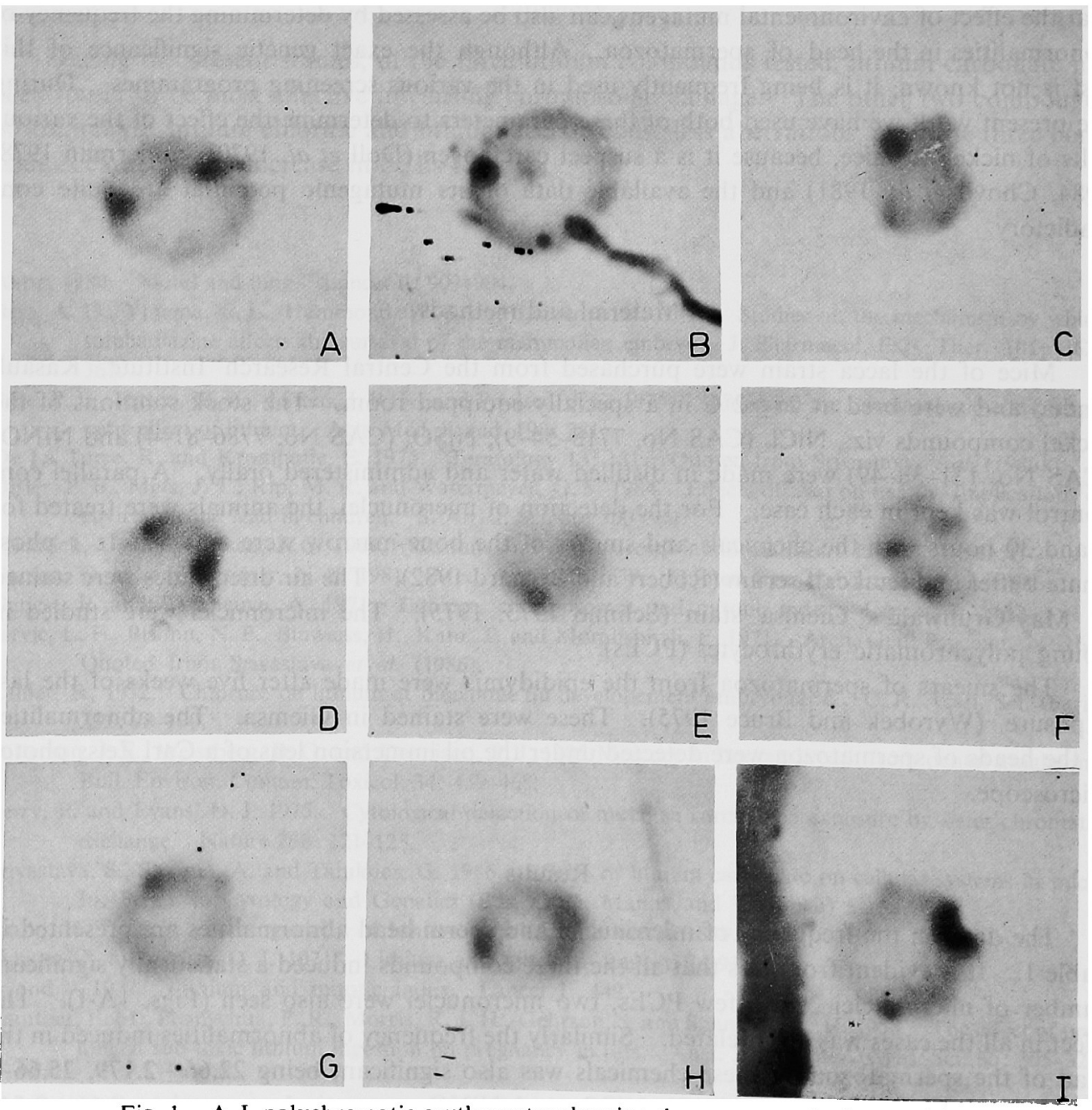

Fig. 1. A-I, polychromatic erythrocytes showing the presence of micronuclei. 
in the controls. The different types of the abnormal spermatozoa were of Daphnia, polyp, amorphous, giant amorphous and anvil-shape (Figs. 2A-I).

\section{Discussion}

The nickel compounds had failed to cause any mutations in $S$. typhimurium and $E$. coli (Sunderman 1981). However, in Coryne bacterium, Pikalec and Nacasek (1983) had observed

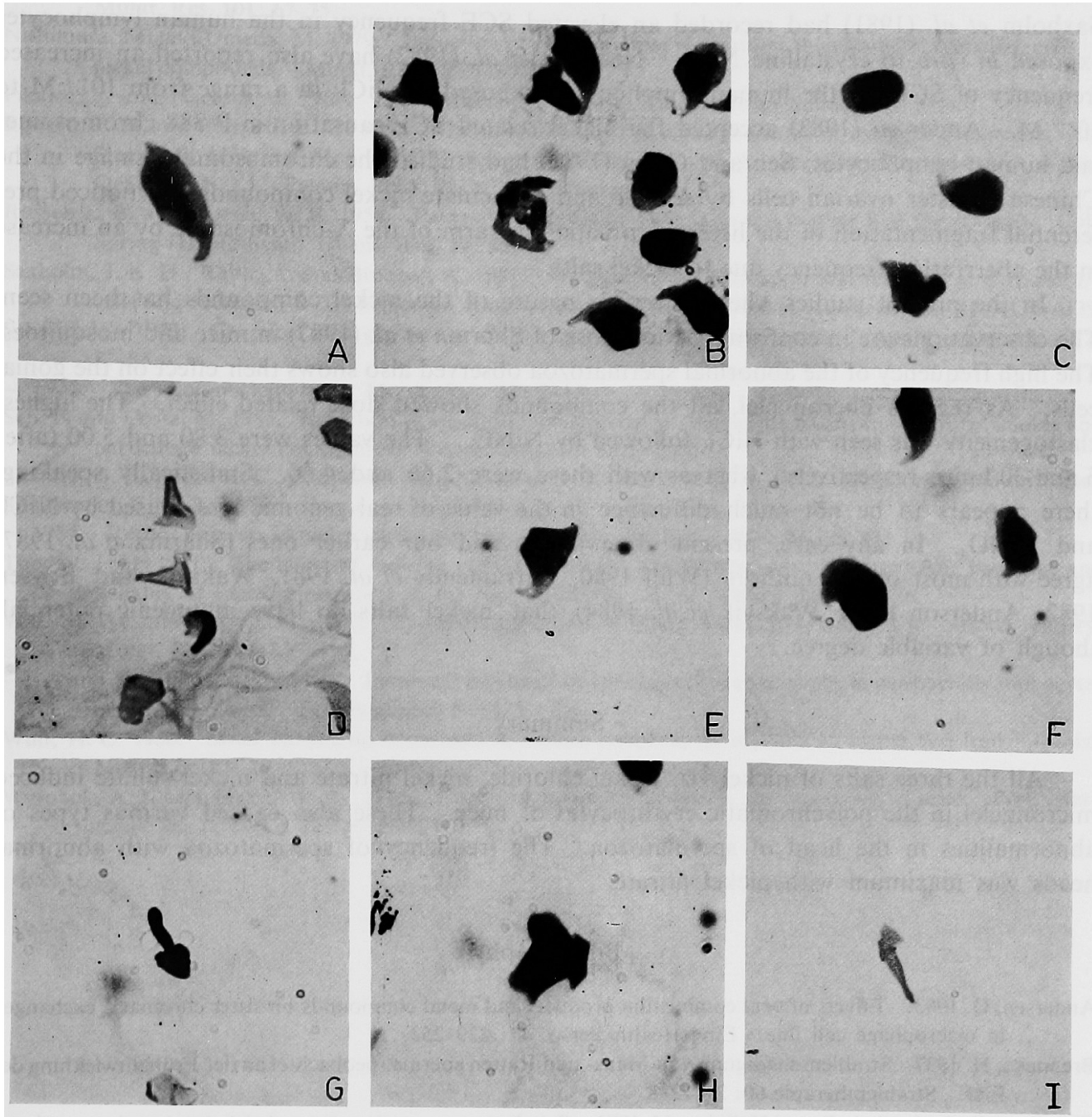

Fig. 2. A-I, various sperm head abnormalities caused by Nickel sulphate.

mutations. Nickel chloride caused mutations in cultured V-79 Chinese hamster cells resistant to 8-azoguanine (Mivaki et al. 1979). Treatment of nickel and other carcinogenic metal cations to the nucleotide bases, renders the DNA susceptible to strand scission or to elimination of bases by an unknown nuclease, resulting in mutations in the repair porcess. Hsie et al. (1979) used 6-thioguanine as a target and found nickel to be mutagenic although caution was indicated by them. In cells exposed to various concentrations of $\mathrm{NiCl}_{2}$ for 3 hours, a dose dependent increase in the absolute number of mutants was found at the thymidine kinase 
locus 51784 in mouse lymphoma cells. Nishimura and Umeda (1979) had reported that certain nickel salts were incorporated in the cells. In vitro exposure of the human lymphocytes to $\mathrm{NiSO}_{4}$, at a concentration as low as $2 \times 10^{-6} \mathrm{M} /$ litre, caused a significant increase in the SCEs (Wulf 1980). It caused chromosomal damage and increased SCE frequency in the Syrian hamster embryo cells and human lymphocytes in cultures (Larramendy et al. 1981). They had also noticed its inhibitory effect on the synthesis of proteins, DNA and RNA. Waksvik and Boysen (1982) and Waksvik et al. (1984) had observed an increase in the incidence of chromosomal aberrations in the peripheral lymphocytes of retired nickel workers. Similarly Saxholm et al. (1981) had recorded an elevated SCE frequency in the human lymphocytes exposed in vitro to crystalline $\mathrm{Ni}_{3} \mathrm{~S}_{2}$. Newman et al. (1982) have also reported an increased frequency of SCEs in the human lymphocytes, exposed to $\mathrm{NiCl}_{2}$ in a range from $10^{-4} \mathrm{M}$ to $10^{-6} \mathrm{M}$. Andersen (1983) accepted the nickel related SCE causation in P 388 chromosomes and human lymphocytes. Sen and Costa (1985) had studied the chromosomal damage in the Chinese hamster ovarian cells by soluble and particulate nickel compounds and noticed preferential fragmentation of the heterochromatic long arm of the X-chromosome by an increase in the aberrration frequency due to nickel salts.

In the present studies, the clastogenic nature of the nickel compounds has been seen. The observations are in conformity with those of Sharma et al. (1987) in mice and mosquitoes. The high frequency of the abnormal spermatozoa observed also shows their effect on the gonial cells. As regards micronuclei, all the compounds showed dose related effect. The highest clastogenicity was seen with $\mathrm{NiCl}_{2}$ followed by $\mathrm{NiNO}_{3}$. The values were 3.80 and 5.00 (after 6 and 30 hours respectively), whereas with these were 2.66 and 4.66. Statistically speaking, there appears to be not much difference in the value of real genomic loss caused by $\mathrm{NiCl}_{2}$ and $\mathrm{NiNO}_{3}$. In any case, present observations and our earlier ones (Sharma et al. 1987) agree with most of the authors (Wulf 1980, Larramendy et al. 1981, Waksvik and Boysen 1982, Anderson 1983, Waksvik et al. 1984) that nickel salts do have mutagenic potential, though of variable degree.

\section{Summary}

All the three salts of nickel viz. nickel chloride, nickel nitrate and nickel sulfate induced micronuclei in the polychromatic erythrocytes of mice. These also caused various types of abnormalities in the head of spermatozoa. The frequency of spermatozoa with abnormal heads was maximum with nickel nitrate.

\section{Bibliography}

Andersen, O. 1983. Effects of coal combustion products and metal compounds on sister chromatid exchanges in macrophage cell line. Env. Health Persp. 47: 239-253.

Brenneke, H. 1937. Strahlenschädigung von Maus- und Ratten sperma, beobachtet an der Frühentwicklung der Eier. Strahlentherapie 60: 214-238.

Chovil, A., Sutherland, A. B. and Halliday, M. 1981. Respiratory cancer in cohort of nickel sinker plant workers. Br. J. Ind. Med. 38: 327-333.

Doll, R., Morgan, G. and Speizer, F. E. 1970. Cancer of the lung and nasal in nickel workers. Br. J. Cancer 24: 623-632.

Evans, H. J., Naeasry, G. J. and Williamson, F. S. 1959. The relative biological efficiency of single doses of fast neutrons and gamma-rays on Vicia faba roots and the effect of oxygen Part II. Chromosome damage. The production of micronuclei. Int. J. Radiat. Biol. 1: 216-229.

Heddle, J. A. 1973. A rapid in vivo test for chromosomal damage. Mutat. Res. 18: 187-190.

Hsie, A. W., Johnson, M. P., Couch, D. B. P., Sansebastian, J. P., O'Neill, J. P., Hoeschelle, J. E., Rahn, R. O. and Farbes, N. L. 1979. Quantitative mammalian cell mutagenesis and a preliminary study of the mutagenic potential of metallic compounds. In. Kharasch, N. (ed). "Trace Metals in Health and 
Disease", Raven Press, N.Y. pp. 55-69.

Larramendy, M. L., Nicholas, C. P. and DiPaolo, J. A. 1981. Induction by inorganic metal salts of sister chromatid exchanges and chromosome aberrations in human and Syrean hamster cell strains. Environ. Mutagens 3: 597-606.

Mather, K. 1937. The experimental determination of the time of chromosome doubling. Proc. R. Soc. Lond. B. 124: $97-106$.

Miyaki, M., Akamatsu, M., Ono, T. and Koyama, H. 1979. Mutagenicity of metal cations in culture cells from Chinese hamster. Mutat. Res. 68: 259-263.

Newman, S. M., Summit, R. L. and Nunez, L. J. 1982. Incidence of nickel induced sister chromatid exchanges. Mutat. Res. $101: 67-75$.

Nishimura, M. and Umeda, M. 1979. Induction of chromosomal aberrations in cultured mammalian cells by nickel compounds. Mutat. Res. $68: 337-349$.

Pikalec, P. and Nacasek, J. 1983. Folia Microbiol. 28: 17. Quoted from Sunderman 1984.

Robert, R. R. and Bernard, E. M. 1982. The micronucleus test as an indicator of mutagenic exposure. In: Single-cell Mutation Monitoring Systems: Methodologies and Applications (Eds. Ansari, A. A. and DeSerres, F. J.). Plenum Press, N.Y. and London.

Russel, L. B. and Russel, W. E. 1954. Pathways of radiation effects in the mother and the embryo. Cold Spring Harbor Symp. Quant. Biol. 19: 50-59.

Saxholm, J. K. H., Reith, A. and Brogger, A. 1981. Oncogenic transformation and cell lysis in $\mathrm{C}_{3} \mathrm{H} / 1071 / 2$ cells and increased SCEs in human lymphocytes by nickel subsulfide. Cancer Res. 41: 4136-4139.

Schmid, W. 1973. Chemical mutagen testing on in vivo somatic mammalian cells. Agents and Actions 3/2: $77-85$.

- 1975. The micronucleus test. Mutat. Res. 31: 9-15.

Sen, P. and Costa, M. 1985. Induction of chromosomal damage in Chinese hamster ovary cells by soluble and particulate nickel compounds. Cancer Res. 45: 2320-2325.

Sharma, G. P., Sobti, R. C., Chaudhry, A., Ahluwalia, K. K. and Gill, R. K. 1987. La Kromosomo (in Press).

Sunderman, F. W. Jr. 1978. Carcinogenic effects of metals. Fed. Proc. 37: 40-46.

- 1984. Recent progress in nickel carcinogenesis. Toxicol. Environ. Chem. 8: 235-252.

Thoday, J. M. 1951. The effect of ionizing radiations on the broad been root. Chromosome breakage and lethality of ionizing radiation to the root meristem. Br. J. Radiol. 24: 572-576.

Waksvik, M. and Boysen, M. 1982. Cytogenetic analysis of lymphocytes from workers in a nickel refinery. Mutat. Res. 103: 185-190.

-, - and Hogetveit, A. C. 1984. Increased incidence of chromosomal aberrations in peripherally mphocytes of nickel workers. Carcinogenesis 5: 1525-1527.

Wulf, H. C. 1980. Sister chromatid exchanges in human lymphocytes exposed to nickel and lead. Danish Med. Bull. 27: 40-42.

Wyrobek, A. J. and Bruce, W. R. 1975. Chemical induction of sperm abnormalities in mice. Proc. Natl. Acad. Sci. (U.S.A.). $72: 4425-4429$. 